Review article

\title{
The prevention of healthcare associated urinary tract infections from the point of view of nursing care
}

\author{
Jitka Krocová ${ }^{1,2}{ }^{*}$, Radka Prokešová ${ }^{1}$, Jana Horová ${ }^{1,2}$ \\ ${ }^{1}$ University of South Bohemia in České Budějovice, Faculty of Health and Social Sciences, České Budějovice, Czech Republic \\ ${ }^{2}$ University of West Bohemia, Faculty of Health Care Studies, Department of Nursing and Midwifery, Pilsen, Czech Republic
}

\begin{abstract}
The goal of this study was to summarize the conclusions of the studies on the efficiency of measures regarding the prevention of healthcare associated urinary tract infections (CAUTI) and to focus on the specifics of nursing care in this area. The included studies and articles were searched for in the electronic databases focused on nursing and other medical fields. The sources were in full text (Cinahl, Ebsco, NursingOvid, ProQuest STM + Hospital Colection - Medline, Science Direct) and citation texts (PubMed, Scopus). They were used for secondary searching of relevant sources. We searched for the selected studies using the following keywords: prevention, risk, infection, urinary tract, efficiency, nursing, as well as according to our criteria (full text, reviewed periodicals, English language) and the period of publishing research results in the last 7 years (2011-2018). We finally included 11 studies that fulfilled the required criteria. The studies (qualitative, observational, quasi-experimental, descriptive) mostly specify the risky areas regarding healthcare associated urinary tract infections and deal with the efficiency of implemented preventative measures which arise from the recommended preventative guidelines CAUTI. Multifactorial measures seem to be positive - education of medical workers regarding the given issue, starting protocols regarding the care of patients with a urinary catheter, standards of care and accepting relevant indications regarding the catheterization of urinary bladder.
\end{abstract}

Keywords: Efficiency; Infection; Urinary tract; Nursing; Prevention; Risk

\section{Introduction}

Urinary tract infections represent one third of the total healthcare associated infections (Catheter-associated urinary tract infection - CAUTI), i.e. such an infection is the most frequent one (Andreessen et al., 2012; Carter et al., 2014; Jindrák et al., 2014; Purvis et al., 2014; Yatim et al., 2016). Purvis et al. (2014) and other authors (Carter et al., 2016; Powers, 2016) state that this infection is associated with the increase of morbidity and mortality. Jindrák et al. (2014) say that the impacts of such infections are lower considering their attributive mortality. More than $80 \%$ of these infections occur when a catheter is inserted (Carter et al., 2014; Jindrák et al., 2014; Powers, 2016; Underwood, 2015; Yatim et al., 2016). The risk of CAUTI increases by $5 \%$ every day after catheterization (Underwood, 2015), and after 30 days the risk is almost 100\% (Andreessen et al., 2012; Jain et al., 2015; Jindrák et al., 2014). Therapy costs and the prolongation of hospitalization are important in these cases. In the USA, the costs for CAUTI treatment are estimated to be 450 million dollars a year (Alexaitis and Broome, 2014; Andreessen et al., 2012; Fuchs et al., 2011). To establish relevant preventative measures, it is crucial to accept the recommended guidelines, which are periodically updated. Using the correct preventative guidelines can prevent $20-70 \%$ CAU-
TI (AACN Practice Alert, 2016; McNeill, 2017; Podrazilová, 2016). Using the assessment of risks of CAUTI, the crucial areas were established, such as prolonged catheterization, examinations or operations of the urogenital tract, repeated disconnection of a draining system, an incompetent medical worker, low quality nursing care and the patient (Andreessen et al., 2012; Jain et al., 2015; Jindrák et al., 2014; Jirouš, 2012; Sujijantararat et al., 2005; Underwood, 2015). The mentioned information shows that the risks of CAUTI arise from a number of areas and the preventative measures must be dealt with comprehensively (Marečková et al., 2015). In relation to the currency of the topic and the effort to implement efficient preventative measures into practice on the basis of EBP (Evidence-based practice), it is possible to follow the risk assessments of the occurrence of CAUTI by Jindrák et al. (2014), who show the data on preventative guidelines and measures of CAUTI. Important preventative steps seem to be relevant indications regarding catheterization, the right technique of inserting urinary catheters and a responding care according to the standard procedures of care of urinary catheters (Jindrák et al., 2014; Jirouš, 2012; Podrazilová, 2016). The procedural quality indicators regarding CAUTI focus on care procedures. If they are not respected, the risk of infections is increased (Jindrák et al., 2014). The authors' intention was to determine complex preventative measures regarding CAUTI on the basis

\footnotetext{
* Author for correspondence: Jitka Krocová, University of West Bohemia, Faculty of Health Care Studies, Department of Nursing and Midwifery, Husova 11, 30100 Pilsen, Czech Republic; e-mail: krocovaj@kos.zcu.cz http://doi.org/10.32725/kont.2019.008

Submitted: 2018-09-14 • Accepted: 2019-01-05 • Prepublished online: 2019-04-03 
of the current recommended procedures which follow EBP. Using the current and best scientific evidence in deciding about the guidelines of care is common practice (Marečková et al., 2015). The current priority in nursing is providing quality and safe care.

\section{Materials and methods}

The main goal of this study was to find the efficient prevention strategies regarding CAUTI from the point of view of nursing care of hospitalized patients. We used the PICO guideline to establish the question of "FOREGROUND" type: P - Patient/ Problem (hospitalized adult patient with a urinary catheter/ the risk of CAUTI); I - Intervention (preventative measures regarding CAUTI); C - Comparison (a patient without intervention or the period before and after intervention); $\mathrm{O}$ - Outcome (the number of CAUTI, days with a catheter) (Marečková et al., 2015): "Are hospitalized adult patients with a urinary catheter $(P)$ after the implementation of efficient preventative measures regarding CAUTI (I) at a lower risk of CAUTI (O) when compared to adult patients with a urinary catheter without the implementation of preventative measures (C)?"

We searched for sources in full-text electronic databases focused on nursing and healthcare. We searched for full texts after studying their abstracts and assessing them as relevant or potentially relevant. The keywords were: prevention, risk, infection, urinary tract, efficiency and nursing. The time range for the search was set to seven years (2011-2018). The main reasonn we chose this period was that the current recommended guidelines (Guidelines for the Prevention of Catheter-associated Urinary Tract Infections) were published in 2009, so the authors chose the interval due to the possible implementation of new recommended guidelines and the possibility of assessing the efficiency of the established study methods. The condition for inclusion was a full text published in English. The CAUTI intervention preventative programme was treated as a measure implemented in institutions whose goal was decreasing the number of CAUTI. The efficiency was defined as a decrease of the number of CAUTI or a decrease of the number of catheterization days in an institution/department where the research was carried out. The criteria were established according to Jindrák et al. (2014), who set the parameters as the resulting indicators of quality. The efficiency was assessed in the concluding assessment of selected studies, which is shown in Table 1 . The exclusive factors were studies in homecare, unavailability of a full text, studies carried out at paediatric departments, and one study which assessed only the economic impact of the interventions. In the end we included 11 studies. One study was qualitative, one was quasi-experimental, one was observational, one was descriptive, and there were 7 other studies in which the authors did not specify the study type. The level of evidence is 2-3 (Marečková et al., 2015). The method of searching relevant research sources is shown in Chart 1 .

Table 1. The interventions of studies and their efficiency

\begin{tabular}{|c|c|c|c|c|c|c|c|c|c|c|c|c|c|c|}
\hline \multirow{2}{*}{$\begin{array}{l}\text { Year } \\
\text { issue, } \\
\text { 1st author } \\
\text { research character } \\
\text { period of research/ev. } \\
\text { number of months }\end{array}$} & \multicolumn{12}{|c|}{ Type of a realized intervention } & \multirow{2}{*}{$\begin{array}{l}\text { Number } \\
\text { of CAUTI } \\
\text { (number of } \\
\text { CAUTI/1000 } \\
\text { days with a } \\
\text { catheter) }\end{array}$} & \multirow{2}{*}{$\begin{array}{l}\text { Days with } \\
\text { a catheter }\end{array}$} \\
\hline & 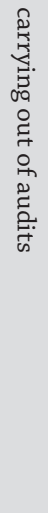 & 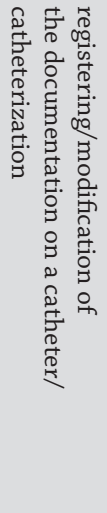 & 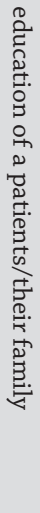 & 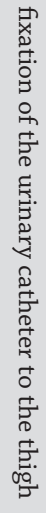 & 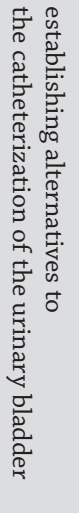 & 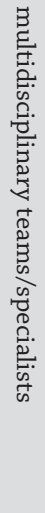 & 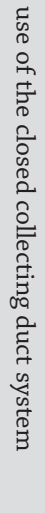 & 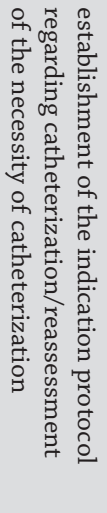 & 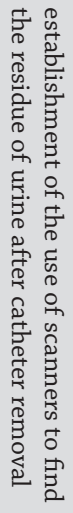 & $\begin{array}{l}0 \\
0 \\
0 \\
0 \\
0 \\
2 \\
0 \\
0 \\
0 \\
0 \\
0 \\
0 \\
5 \\
5 \\
5 \\
0 \\
0 \\
0 \\
0 \\
0 \\
0 \\
0 \\
0 \\
0 \\
0\end{array}$ & 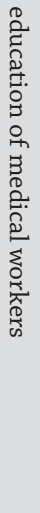 & 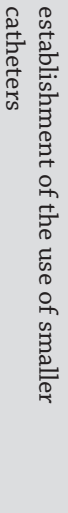 & & \\
\hline $\begin{array}{l}\text { Fuchs et al. (2011), } \\
\text { descriptive study } \\
7 / 2009-2 / 2010 \text {, } \\
8 \text { months }\end{array}$ & - & + & - & - & - & + & - & + & + & - & - & - & $\begin{array}{c}\downarrow \text { from } 2.88 \rightarrow \\
1.46\end{array}$ & $\begin{array}{l}\downarrow \text { from } 402 \\
\rightarrow 380\end{array}$ \\
\hline $\begin{array}{l}\text { Oman et al. (2012), } \\
\text { study } \\
12 / 2008-2 / 2010 \text {, } \\
15 \text { months }\end{array}$ & + & + & + & + & + & + & - & + & - & - & + & - & $\begin{array}{l}\text { pulmonary } \\
\text { department } \\
0 \text {, surgical } \\
\text { department } \\
\downarrow \text { from } 3.4 \\
\rightarrow 2.2\end{array}$ & $\begin{array}{c}\downarrow \text { surgical } \\
\text { department } \\
\text { from } 3.01 \\
\rightarrow 2.2 \\
\downarrow \\
\text { pulmonary } \\
\text { department } \\
3.53 \rightarrow 2.7\end{array}$ \\
\hline $\begin{array}{l}\text { Andreessen et al. } \\
(2012), \\
\text { study } \\
8 \text { months, no more } \\
\text { specifications }\end{array}$ & & & & & & & & & & & & & $\begin{array}{l}1 \text { CAUTI } \\
\text { case in the } \\
\text { studied period } \\
\text { after the } \\
\text { establishment } \\
\text { of the } \\
\text { interventions }\end{array}$ & $\begin{array}{l}\downarrow \text { from } 505 \\
\quad \rightarrow 148 \\
(\downarrow \text { by } 71 \%)\end{array}$ \\
\hline
\end{tabular}




\section{Table 1 (continued)}

\begin{tabular}{|c|c|c|c|c|c|c|c|c|c|c|c|c|c|c|}
\hline \multirow{2}{*}{$\begin{array}{l}\text { Year } \\
\text { issue, } \\
\text { 1st author } \\
\text { research character } \\
\text { period of research/ev. } \\
\text { number of months }\end{array}$} & \multicolumn{12}{|c|}{ Type of a realized intervention } & \multirow{2}{*}{$\begin{array}{l}\text { Number } \\
\text { of CAUTI } \\
\text { (number of } \\
\text { CAUTI/1000 } \\
\text { days with a } \\
\text { catheter) }\end{array}$} & \multirow{2}{*}{$\begin{array}{l}\text { Days with } \\
\text { a catheter }\end{array}$} \\
\hline & 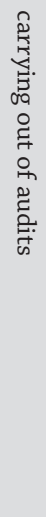 & 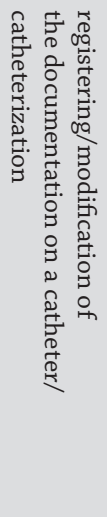 & 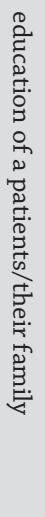 & 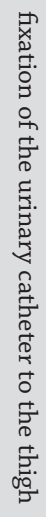 & 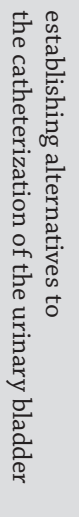 & 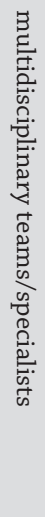 & 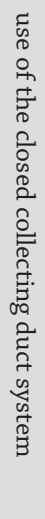 & 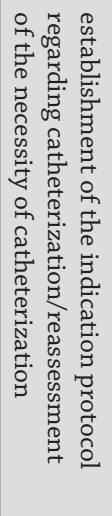 & 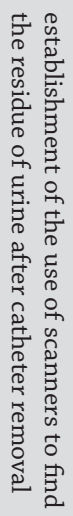 & $\begin{array}{l}0 \\
0 \\
0 \\
0 \\
0 \\
0 \\
0 \\
0 \\
0 \\
0 \\
0 \\
0 \\
0 \\
0 \\
0 \\
0 \\
0 \\
0 \\
0 \\
0 \\
0 \\
0 \\
0 \\
0 \\
0 \\
0\end{array}$ & 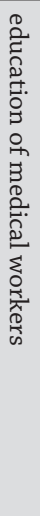 & 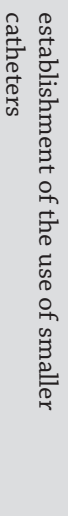 & & \\
\hline $\begin{array}{l}\text { Alexaitis and Broome } \\
\text { (2014), } \\
\text { study } \\
\text { not specified, probably } \\
2013\end{array}$ & - & - & - & - & + & - & - & + & + & - & + & - & $\begin{aligned} \downarrow & \text { from } 3.85 \\
\rightarrow & 3.06(\downarrow \text { by } \\
& 20.5 \%)\end{aligned}$ & \\
\hline $\begin{array}{l}\text { Purvis et al. (2014), } \\
\text { study } \\
1 / 2011-2 / 2013\end{array}$ & + & + & - & - & - & + & - & + & - & - & + & - & $\begin{array}{l}\downarrow \text { from } 4.2 \\
\quad \rightarrow 2.4\end{array}$ & $\begin{array}{l}\downarrow \text { from } 5.11 \\
\quad \rightarrow 2.59\end{array}$ \\
\hline $\begin{array}{l}\text { Carter et al. (2014), } \\
\text { study 10/2011- } \\
12 / 2013\end{array}$ & + & + & - & - & - & - & - & + & - & + & - & - & $\begin{array}{l}\downarrow \text { of the } \\
\text { number- not } \\
\text { specified; at } \\
\text { the end of } \\
\text { the study - } \\
\text { number } 0\end{array}$ & \\
\hline $\begin{array}{l}\text { Underwood (2015), } \\
\text { study } \\
1-6 / 2012 \text { and } \\
1-6 / 2013\end{array}$ & - & + & - & - & - & - & - & + & - & + & + & - & $\begin{array}{c}\downarrow \text { from } \\
7,6 \rightarrow 7,2 \\
(\downarrow \text { by } 19 \%)\end{array}$ & $\begin{array}{c}\downarrow \text { from } 458 \\
\rightarrow \quad 401,5(\downarrow \\
\text { by } 14 \%)\end{array}$ \\
\hline $\begin{array}{l}\text { Carter et al. (2016), } \\
\text { qualitative study } \\
9 / 2011-6 / 2012\end{array}$ & - & - & - & - & + & + & - & + & - & + & - & - & $\begin{array}{c}\downarrow \text { of the } \\
\text { number- not } \\
\text { specified }\end{array}$ & $\begin{array}{l}\downarrow \text { of the } \\
\text { number } \\
\text { - not } \\
\text { specified }\end{array}$ \\
\hline $\begin{array}{l}\text { Powers (2016), } \\
\text { observation study } \\
\text { approximately } 23 \\
\text { months, period not } \\
\text { specified }\end{array}$ & - & - & - & - & - & + & - & - & + & + & - & - & $\begin{array}{l}4 \text { cases in } 8 \\
\text { months }\end{array}$ & $\begin{array}{c}\text { not } \\
\text { specified }\end{array}$ \\
\hline $\begin{array}{l}\text { Yatim et al. (2016), } \\
\text { study 11/2013- } \\
2 / 2015\end{array}$ & - & - & - & - & - & - & - & + & + & - & + & - & $\begin{array}{c}4 \rightarrow 0 \\
\text { (comparison } \\
\text { of the pre- } \\
\text { implemen- } \\
\text { tation period } \\
-9 \text { months } \\
\text { - and the } \\
\text { post- } \\
\text { implementa- } \\
\text { tion period - } \\
6 \text { months) }\end{array}$ & $\begin{array}{c}\text { increase (by } \\
0.12-0.18)\end{array}$ \\
\hline $\begin{array}{l}\text { Peter et al. (2018), } \\
\text { quasi-experimental } \\
\text { study, not specified }\end{array}$ & + & - & - & - & - & - & + & + & - & + & + & - & $\begin{array}{l}\text { after the } \\
\text { implemen- } \\
\text { tation of } \\
\text { the CAUTI } \\
\text { measures 0 - } \\
\text { not specified }\end{array}$ & \\
\hline
\end{tabular}




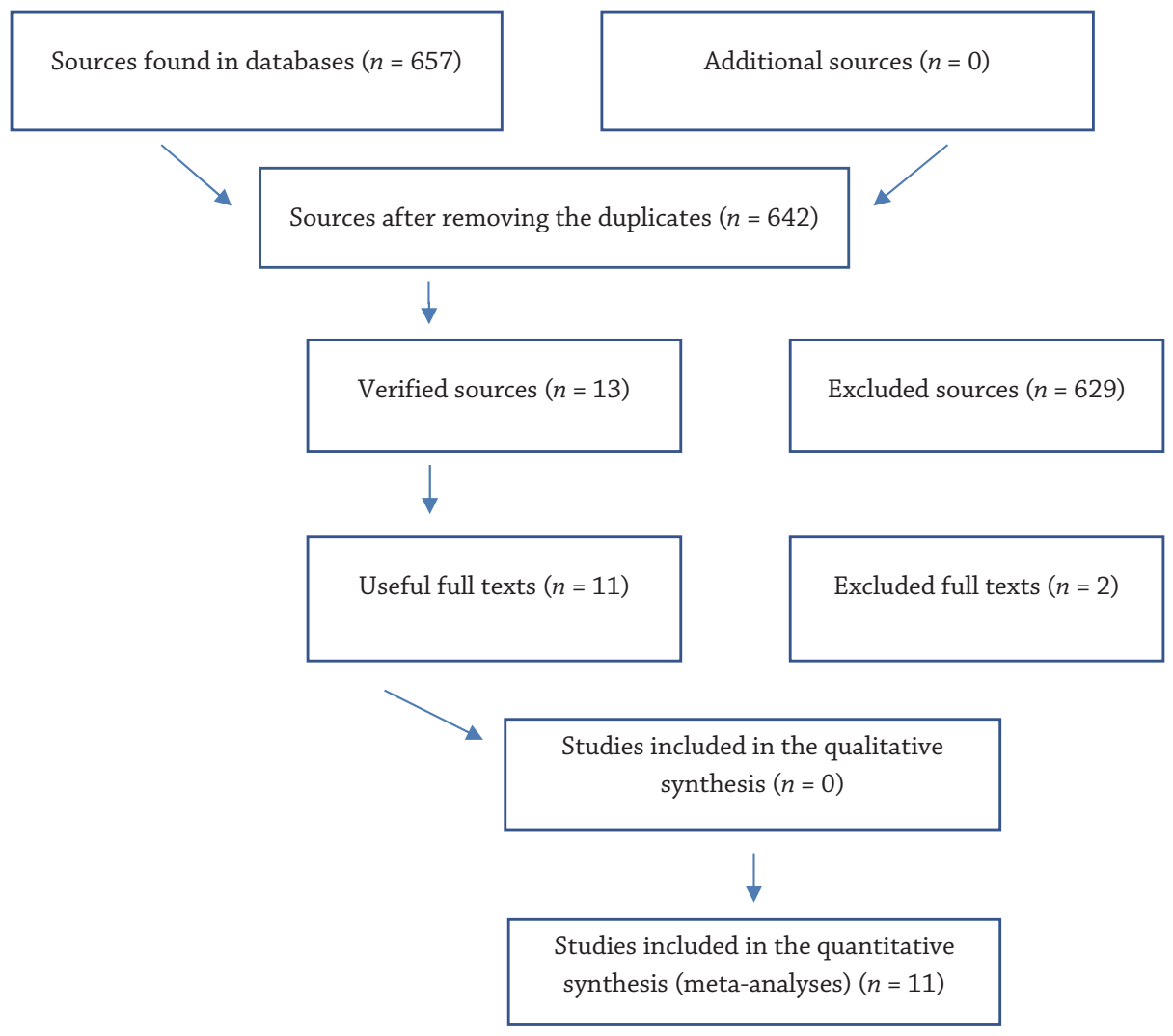

Chart 1. The method of a relevant source search - PRISMA diagram

\section{Results}

The research included 11 studies (Alexaitis and Broome, 2014; Andreessen et al., 2012; Carter et al., 2014; 2016; Fuchs et al., 2011; Oman et al., 2012; Peter et al., 2018; Powers, 2016; Purvis et al., 2014; Underwood, 2015; Yatim et al., 2016). The efficiency of the established preventative measures was assessed in eight studies using the number of CAUTI or days with a catheter or both. The author of the qualitative study included the respondents' statement that there had been a decrease in the number of CAUTI and days with a catheter. Powers (2016) included the percentage of CAUTI cases in his observational study for the study period. Carteret et al. published their study carried out in the post-interventional period in 2014, where they stated zero CAUTI cases. The comparison of the number of CAUTI in the pre-interventional (4 cases of CAUTI/9 months) and post- interventional period ( 0 cases of CAUTI/ 6 months) is described in the results of Yatimet et al. (2016). Two studies also showed the economic effect of established preventative measures (Alexaitis and Broome, 2014; Oman et al., 2012). The studies included an experimental and a control group of patients (Alexaitis and Broome, 2014; Peter et al., 2018; Underwood, 2015). The observation study showed the number of CAUTI in relation to the number of studied performances (Carter et al., 2016), and the others compared the pre-intervention and post-intervention periods (Andreessen et al, 2012; Carter et al., 2014; Fuchs et al., 2011; Oman et al., 2012; Powers, 2016; Purvis et al., 2014; Yatim et al., 2016).

\section{The recommended guidelines of the prevention of CAUTI}

In 2009, the Healthcare Infection Control Practices Advisory Committee (HICPAC) and The Centers for Disease Control and Prevention - CDC (Gould et al., 2009) published the updated directive for the prevention of CAUTI. This recommended guideline updates and broadens the previous version of recommended guidelines from 1981, which was published by CDC. The Guideline for Prevention of Catheter-associated Urinary Tract Infections from 2009 is based on verified evidence-based interventions. It emphasizes prevention and clearly defines goals as well as the preventative steps and result indicators. The updated recommendations include preventative guidelines for the ill whose condition requires a chronic urinary catheterization, and patients who can use alternative options, such as urogenital condoms, intermittent catheterization, and incontinence towels (Hedlová, 2010). The Guideline includes a modified HICPAC categorization graph. In 2001, the HAI instructions were issued. The phase of one instruction included the CAUTI preventative measures. In 2008, the European Association of Urology (EAU) and the Urological Association of Asia (UAA) issued the document of Management and Prevention of the Catheter-associated Urinary Tract Infections. In the same years, the Society for Healthcare Epidemiology of America (SHEA) issued a summary of the recommendations regarding the preventative methods regarding infections in healthcare, including CAUTI. A year later, the company Wound, Ostomy and Continence Nurses Society (WOCN) published nursing interventions to decrease the risk of catheter-associated urinary 
tract infections (Conway and Larson, 2012; Tenke et al., 2008; Trautner, 2010). The Infectious Diseases Society of America (IDSA) published an international recommendation regarding the diagnostics, prevention and treatment of CAUTI (Conway and Larson, 2012).

\section{The assessment of the efficiency of preventative steps}

We included 11 studies from between 2011 and 2018 (Alexaitis and Broome, 2014; Andreessen et al., 2012; Carter et al., 2014; 2016; Fuchs et al., 2011; Oman et al., 2012; Peter et al., 2018; Powers, 2016; Purvis et al., 2014; Underwood, 2015; Yatim et al., 2016). The authors of this article describe the implementation of the preventative measures in the studies and monitor their efficiency. Rather than one intervention, "packages" or sets of measures were implemented. Only one study assessed the efficiency of the implementation of one preventative step (Powers, 2016). The studies of Purvis et al. (2014), Andresseen et al. (2012), Carter et al. (2014; 2016), Yatim et al. (2016), Underwood (2015), Fuchs et al. (2011), Alexaitis and Broome (2014), Oman et al. (2012) and Peter et al. (2018) share a common intervention from the set of measures, which is the implementation of indication protocols for catheterization and the reassessment of the necessity of catheterization. The mentioned measures in individual studies include other interventions as well. The descriptive study of Fuchs et al. (2011) was carried out between July (2009) and February (2010) at intensive care units (90\% of patients had a urinary catheter). The preventative step was the implementation of the Duke Infection Control Outreach Network (DI$\mathrm{CON}$ ) protocol. It contains a clear chart of the assessment of catheterization indication; it serves for a daily reassessment of the necessity of catheterization.

In the first phase, nurses were trained by the members of a multidisciplinary team in the prevention of CAUTI and the use of the protocol. The document was implemented in the hospital IT system. A part of the study was a research regarding the satisfaction with the implemented protocol. The result of the implementation of the protocol was a decrease in the number of days with a catheter from 402 to 380 and a decrease in the number of CAUTI at intensive care units from 2.88 to 1.46 , which is not statistically significant $(p=0.068)$ but it is an important decrease from the point of view of clinical practice (Fuchs et al., 2011). The HOUDINY protocol was later used as a part of the prevention in studies and the efficiency of the implemented preventative steps was proven. The goal of the study (Underwood, 2015) was to find the efficiency of the interventions to decrease the number of CAUTI. The study was carried out in 2012. Its preparation phase was followed by the post-implementation phase in 2013 . In this case, the implemented measures of CAUTI enabled the realization of educational programmes for employees, the implementation of standard methods of care of urinary catheters, which correspond with the EBN (Evidence-based nursing), and the implementation of the HOUDINY process (for the reassessment of catheterization indication).

The facility had implemented standard guidelines for catheterization and care of a catheter and a urinary bag, including the CAUTI preventative measures and the HOUDINY process. The study included 936 patients (implementation phase) and 902 in the post-implementation period. The result of the implementation of measures was a total decrease in the number of catheterization days from 458 to 401.5 (14\%). The number of CAUTI decreased by $19 \%$ but was not statistically significant (from $7.6 \rightarrow 7.2$ ). According to Underwood (2015), the necessity of the implementation of standard methods of care and catheterization was confirmed, as well as the education of personnel and the implementation of unified criteria for the indication of catheterization. She perceives the limits of her study to be the relatively low number of respondents. The efficiency of the implementation of the HOUDINY process and a daily reassessment of the catheterization indication by nurses were studied by Yatim et al. (2016) at a station with 75 beds. Before the beginning of the study, the education of nurses was included - indication assessment, urinary scanner after catheter removal. The result of the six-month study after the implementation of measures was a slight increase in the number of catheterization days. According to the authors, it was probably caused by the composition of patients; there were no cases of CAUTI. The results were compared to the monitored nine-month pre-implementation period, which showed 4 cases of CAUTI (Yatim et al., 2016).

The efficiency of the implementation of the protocol/documentation of nurses (containing the indication of catheterization and the necessity of daily reassessment of whether a catheter is necessary) was assessed by Alexaitis and Broome (2014). Their study was carried out at a neurosurgical intensive care unit. They found a higher number of catheterization days and CAUTI $(<58 \%)$ than at other units $(22 \%)$. At the end of the study, they used the FADE method (Focusing on the problem; Analyzing data; Developing a plan to reduce CAUTIs; Executing the plan and Evaluating results). Before the beginning, an audit was used to find insufficient knowledge of nurses in the care of patients with a urinary catheter, indications of catheterization, the management of the reassessment of catheterization indications was not unified, nurses were not trained in using the instruments for checking the residual urine after catheter removal. At the beginning of the study, nurses completed an educational programme and skills practice, a catheter care protocol was implemented (record of catheterization data, size and type of catheter, daily reassessment of indication, care of catheter/hygiene, education of patients and their families), and an audit was carried out, which confirmed a $98 \%$ concordance with the nursing care protocol (previously $89.3 \%$ ) and a total improvement in complex care from 85.9 to $90.1 \%$. They compared 322 patients with a control group of $497 \mathrm{pa}-$ tients. The result was a decrease of CAUTI by $20.5 \%$ : from 3.85 to 3.06. The average costs of medicines and supplies and the methods of the CAUTI treatment decreased by $40.7 \%$, and the period of using a catheter was shorter by 2.5 days. However, the author adds that the project assessment was carried out after two months and only at one hospital unit. A significant statistical relevance of implemented measures was not proven. Nevertheless, preventative steps should be implemented in the hospital and reassessed due to their larger quantity (Alexaitis and Broome, 2014).

The study from 2009 (Oman et al., 2012) shows that an interdisciplinary team for prevention initiated a project for the increase of the quality of care, and implemented the recommended interventions of nurses that led to the prevention of CAUTI. The project implemented the following measures: a multidisciplinary team of specialists, the reassessment of used materials and prices, the available catheter types, urinary bags and aids for the alternative insurance of the derivation of urine, the availability of the instruments for finding the urinary residue and the implementation of clinical information system (records on the number of CAUTI/1000 catheterization days, number of hospitalization days/catheterization days, days of a post-operation catheterization/patients). The project had 3 phases and was carried out at surgical units (general surgery and pulmonary surgery). There were 150 patients 
at the general surgery unit and 125 at the pulmonary unit. Based on the recommendations through verified practice, they implemented the following steps in the 2 nd project phase: the implementation of latex catheters with a silicone layer, the implementation of sets for catheterization including a urinary bag, educational programmes for non-medical healthcare personnel (including physiotherapists, transportation employees or radiological assistants). The education included information about the CAUTI prevention. In the third phase, they carried out an educational programme for nurses, where it was possible to discuss the issue and the training regarding the use of instruments/scanners. They also implemented the protocol on catheter care with a suggestion of the reassessment of catheter indication. An educational programme for patients and their relatives was implemented. The result of the measures implemented during the 6 months was a 96\% personnel training, a decrease in the number of catheterization days from 3.01 to 2.2 at the surgical department, at the pulmonary department the decrease was 3.53 to 2.7 , and there was also a $\$ 52,000$ saving (Oman et al., 2012).

The study of Andreessen et al. (2012) on the implementation of measures at the departments of acute care lasted 8 months and it compared the data in computer patient records $-1,200$ before and 1,385 after the programme implementation. The results were published by Andreessen et al. (2012). The first step was the establishment of a multidisciplinary team, education of nurses regarding the care of catheters and the implementation of the CAUTI preventative principles. The implemented measures included the following: catheterization indication according to the Guidelines 2009, the use of enclosed urinary bags, the choice of a smaller catheter size (if possible), respecting the principles of hand hygiene, aseptic method during catheterization, the fixation of a catheter to the thigh, keeping a record on a catheter and a daily reassessment of the necessity of catheterization. The result was an improvement in keeping records on catheters to $98 \%$, a decrease in catheterization days by $71 \%$ (from 505 to 148 days), a decrease in the number of catheterizations by $57 \%$, and a decrease in the average catheterization time from 23 days to 9 and three weeks after the implementation of the measures, there was only one case of CAUTI occurred.

The qualitative study of Carter et al., 2016, lasted nine months (2011-2012). It was carried out at a reception, where $90 \%$ of patients had been given a urinary catheter on the first day. After the implementation of preventative measures, 52 interviews were carried out, and the results clearly showed the large contribution of the nursing management and specialized nurses who were appointed by the management of the CAUTI preventative measures. The importance of this was mainly in the activities regarding the implementation of new methods and the high motivation of nurses to provide quality care. The implemented measures were: the reassessment of the current methods, monitoring the quality of care and procedures using audits, respecting a strict asepsis during catheterization, considering the alternatives for catheterization, the establishment of exact catheterization indications and a daily reassessment of catheterization indication using protocols. The evaluation of the measures implemented was assessed by the number of implemented catheters at the department. According to the authors, the respondents confirmed a decrease in the number of catheterization days and cases of CAUTI. However, specific data are not available (Carter et al., 2016).

The results of the study by Purvis et al. (2014) dealt with the efficiency of similar preventative measures to the previous one (the implementation of the activities of multidisciplinary teams for the prevention and control of infections, protocols for nurses and the education of employees in the issue). The steps of this study included the implementation of a common documentation for nurses and doctors. Its function is a daily reminder of a reassessment of the necessity of catheterization. They also carried out an educational programme for nurses and regular audits of the quality of care. The research was carried out at two 28-bed units (non-surgical and surgical). It included all patients with a urinary catheter. Before the implementation of measures, the authors found the absence of knowledge of the CAUTI preventative measures, leaving a catheter if a patient wished, or in order to make the care easier (incontinence); there were no reassessments of indication. The implementation of measures resulted in a decrease of the average catheterization period from 5.11 to 2.59 per day, as well as the number of CAUTI (from 4.2 to 2.4) (Purvis et al., 2014). The evaluation of the CAUTI preventative measures implemented at the department of reception and intensive care is described in the study of Carter et al. (2014). The measures established on the basis of EBP and EBN were the following: the establishment of the indications for catheterization and the reassessment of indication, aseptic method during catheterization, the correct care of catheters and urinary bags, and education of employees. The departments established charts for the reassessments of catheterization indication and a unified documentation for catheter care. The results of this study, which was carried out between October of 2011 and October of 2013 showed a decrease in the number of CAUTI in the last three months ( 0 cases) and a decrease in the number of catheterization days. However, a low number of patients were included in the study and it was only carried out at selected parts of the facility (Carter et al., 2014). Interesting results can be found in the study of Powers (2016). The primary goal was to assess whether there was a relationship between the incidence of CAUTI and the interruption of enclosed urinary collective system provided that aseptic procedure was respected. In 8 months, his study mapped 53 cases of the interruption of the urinary collective system. $92.5 \%$ of patients did not suffer from CAUTI and 4 patients did as a result of the interruption of the urinary collective system (7.5\%). For comparison, the authors state the number of CAUTI during the period spent in the facility, i.e. 3.5 cases in 1,000 catheterization days.

The results of the efficiency of the implemented preventative measures regarding the CAUTI prevention from a quasi-experimental study were published by Peter et al. (2018). The data were collected from 70 respondents (35 were in the control group). Before the start of the study, they implemented a unified updated method and interventions in the CAUTI prevention (strict asepsis during catheterization, the establishment of catheterization indications and monitoring and a daily reassessment of catheterization indication, the care of the urinary catheter and the urinary collective system, the use of an enclosed urinary collective system, the prevention of regressive urine flow, correct urine collection for a microbiological examination). An educational programme for employees was also included. The research assessed the knowledge and control and experimental skills (trained) of a group of nurses, and audits of performances and nursing procedures were carried out. The results confirmed an increase in the quality of care after the training of the experimental group of employees (Peter et al., 2018). The authors concluded the necessity of the education of personnel regarding the issue, regular check-ups of the methods of care and the monitoring of the number of CAUTI and catheterization days in the facility. 
The included studies were summarized in Tab. 1. Besides the identification data, we recorded the periods when the studies were carried out, an overview of the implemented preventative measures for CAUTI and the efficiency indicators of the implemented measures. The interventions/implemented measures were generalized. The evaluation of the preventative interventions of CAUTI was published by Meddings et al. (2014).

\section{Discussion}

The goal of this study was to find the level of the efficiency of implemented measures of CAUTI and to focus on the interventions of nursing care which are related to the prevention of the mentioned infections. Our results show that the basis of preventative measures (according to the results of the studies of Alexaitis and Broome, 2014; Andreessen et al., 2012; Carter et al., 2014; 2016; Fuchs et al., 2011; Oman et al., 2012; Peter et al., 2018; Powers, 2016; Purvis et al., 2014; Underwood, 2015; Yatim et al., 2016) are the recommended guidelines. The guidelines include individual aspects of prevention. The review article by Conway and Larson (2012) compares the preventative methods between 1980 and 2010 (8 methods) and states that the recommendations remain similar. The basic preventative points are relevant catheterization indications, daily reassessments of the necessity of catheterization (longer than 48 hours) and the shortening of the catheterization period to a necessary length, aseptic catheterization technique and the correct care of a catheter and the urinary collective system.

It is also important to keep a record and monitor the number of possible infections, catheterization days and to carry out the audits of care (Tenke et al., 2008; Conway and Larson, 2012). Gould et al. (2009) recommend keeping a standard type of record which should include the following information: who implemented the catheter, date and time, indication and the date of catheter removal. This data can enable the collection of data and the improvement of the quality of care. Trautner (2010) and Conwayand Larson (2012) presented the results of their study which was carried out in 2005 in 719 hospitals that provided acute care. The results showed that only a quarter monitored the number of patients with a urinary catheter and a fifth monitored the catheterization indications (Andreessen et al., 2012; Conway and Larson, 2012; Trautner, 2014). Since 2001, the recommended guidelines define the implementation of regular reassessments of catheterization indication and standardized indication protocols as an efficient preventative tool (Andreessen et al., 2012; Conway and Larson, 2012; Gould et al., 2009; Trautner, 2010). The development of computer technologies offers the implementation of electronic documentation in facilities. With the right management, it can be the central source of information about catheterization indications/ catheterization days and possible CAUTI for the management or epidemiology departments. This step is one of the measures in the mentioned studies (Fuchs et al., 2011; Purvis et al., 2014).

The summary of the recommendations of AACN (AACN Practice Alert, 2016) is related to the nursing point of view. The support in the implemented measures is the use of the catheterization criteria and the reassessments of indications. Implementing the protocol is one of the measures in the studies (Andreessen et al., 2012; Carter et al., 2014; 2016; Fuchs et al., 2011; Oman et al., 2012; Powers, 2016; Purvis, 2014; Underwood, 2015). Fuchs et al. (2011) assess the efficiency of the DICON protocol, and Underwood (2015) and Yatimet al. (2016) the HOUDINY protocol. The studies (Alexaitis and Broome, 2014; Carter et al., 2014; Oman et al., 2012; Purvis, 2014; Underwood, 2015; Yatim et al., 2016) assess the implementation of standardized protocols as highly efficient. There are clear criteria of catheterization indication and the documents serve as reassessments of indications (reminders) and a method of keeping record on catheters. The study of Tenkeet al. (2008) summarizes the current recommendations. The authors compare the advantages and disadvantages of alternative methods of urine derivation. The consideration of catheterization modalities is another preventative measure and some studies (Alexaitis and Broome, 2014; Carter et al., 2016; Oman et al., 2012) include it in preventative measures. It was mentioned that a urinary catheter is often left implemented if the patient wishes so or due to the "facilitation" of nursing care. A prolonged catheterization is one of the risk factors of CAUTI. For this reason, it is necessary to consider the benefits and the risks for the patient related to this way of solving urine derivation. This review has showed that a part of studies (Andreessen et al., 2012; Carter et al., 2014; 2016; Fuchs et al., 2011; Oman et al., 2012; Purvis, 2014; Yatim et al., 2016; Underwood, 2015) was the implementation of measures ("packages"). Only the study of Powers (2016) deals with the monitoring of efficiency of one factor, i.e. keeping the urinary collective system enclosed (establishing preventative principles during the disconnection, which is one of the strong recommendations (Gould et al., 2009; Kohoutová, 2014)).

The results of the study published in 1974 clearly support the use of an enclosed urinary collective system and recommend minimum interventions. Powers (2016) presents the outcomes of the study from 1993, when over 900 patients were monitored. $11 \%$ of them had their system disconnected and 88 developed an infection. However, the authors did not analyze possible aspects of the incidence of bacteriuria. The education of personnel is part of the preventative measures, which is one of the recommendations of the Guideline from 2009 in the Administrative Infrastructure section (Gould et al., 2009; Hedlová, 2010). Jirouš (2012) sees this area as important and states that medical workers must be educated in the principles of CAUTI prevention. The Methodical Instructions of the Ministry of Health of the Czech Republic (2013) states that a provider of healthcare is obliged to organize a training of medical and non-medical workers regarding the prevention of infections, i.e. preliminary and periodical trainings and trainings for emergencies. The education should be carried out by a member of the prevention team and so should the infection check-up. The preventative measures of one study (Oman et al., 2012) mentioned in this article included training of nurses as well as other non-medical employees in the principles of the manipulation of the urinary collective. Purvis (2014) mentions the creation of an internet link for the information on CAUTI in a facility. The personnel have the information available. Based on the continuously increasing IT literacy and skills, an alternative of e-learning is offered. In their study, Oman et al. (2012) implement educational programmes for patients and their relatives. Unfortunately, an evaluation of these programmes was not carried out. The education of patients in homecare is assessed by the randomized clinical study of Wilde et al. (2015). Patients with a long-term catheter were informed about self-monitoring and the result was a decrease in the number of cases of obstructed catheters in the experimental group of patients. According to the authors, such a result was achieved due to maintaining the daily liquid intake. Nevertheless, there was no statistical significance of the results (Meddings et al., 2014). 
The implementation of a multidisciplinary team of specialists was published in the studies of Alexaitis and Broome, 2014, Andreessen et al., 2012, Carter et al., 2016, Fuchs et al., 2011, Oman et al., 2012, Purvis et al., 2014. The task of such teams is the verification of current methods, their update, implementation into practice and controlling the standards of care. Pintar (2013) states that the evidence of EBP shows that the implementation of employees regarding the prevention of infections is a step towards the increase of the level of safety and the quality of care. One of the measures in the study of Andreessen et al. (2012) is the use of the smallest tubes and the fixation of the catheter. It is included in the recommended guidelines. It is a strong recommendation which is supported by weak evidence (AACN Practice Alert, 2016; Andreessen et al., 2012; Gould et al., 2009; Trautner, 2010). Two studies (Alexaitis and Broome, 2014; Oman et al., 2012) published the economic effect of the implemented measures. One (Oman et al., 2012) dealt with the finances saved due to the strategies regarding the choice of material. The financial savings after the implementation of prevention is motivating. In the USA, the costs for CAUTI are not covered, neither are those for the prolongation of hospitalization. The results of the implemented preventative measures are usually shown by the numbers of CAUTI and catheterization days (Alexaitis and Broome, 2014; Andreessen et al., 2012; Fuchs et al., 2011; Oman et al., 2012; Purvis et al., 2014; Underwood, 2015). According to Jindrák et al. (2014), there are 3.1 to 3.7 cases of CAUTI for 1,000 catheterization days. The efficiency of implemented preventative measures was assessed by the decrease of the number of CAU$\mathrm{TI}$ and the comparison of the numbers of catheterization days. The CAUTI registration is more complicated due to the fact that an infection can be asymptomatic. The diagnostics needs the evidence of the presence of a significant quantity of microorganisms in urine (Jindrák et al., 2014). This fact cannot be ignored. It is necessary to record the cases of infections, if possible electronically, and not to underestimate the first symptoms of CAUTI. As a conclusion, it is possible to polemize with the results; this article assesses the effect of qualitative and observational studies which do not present specific results. These intentions may be an inspiration for further research and bring information about the possibilities of research effects regarding the prevention of CAUTI.

\section{The limitations of the study}

This article gives the review of the results of researches which deal with post-implementation preventative measures regard- ing CAUTI. One limitation could be the inclusion of articles that were written only in English. We did not include studies written in other foreign languages. Another limitation is the level of evidence included in this article. A limitation can appear in the results (frequently non-diagnosed asymptomatic cases of CAUTI which were not recorded). The only solution would be to draw samples of urine for a microbiological examination. The authors of the studies included in this review are aware of the limitations of their studies, such as only one hospital type or a certain department/section - the results cannot be globalized to every hospital type or care department. We are also aware of a limitation in the conclusions of the authors and their teams; the parameter of catheterization days was decreased, as well as the number of CAUTI, but the decrease in the number of infections was statistically insignificant, however, clinically significant. The issue in the discussion regarding the limitation of this study is the choice of keywords with "and" (the Boole operator), which led to a large number of irrelevant sources (Mareckova et al., 2015). Another limitation was the selected time interval.

\section{Conclusions}

We are able to say that the last years of the prevention of CAUTI have preferred sets of measures (packages). Studies mostly assess the effect of the implementation of numerous measures and the preventative steps are based on updated recommended guidelines. The implemented measures seem to be efficient, but we cannot ignore the fact that the implementation of any guideline requires a check-up and the efficiency evidence-based assessment (in this case, the number of the cases of CAUTI and catheterization days). Accepting catheterization indication and a daily reassessment of indication seem to be very efficient preventative aspects. Care protocols are a tool for measures. The assumed and verified effect is a decrease in the catheterization period and the elimination of the risk of CAUTI. We must not forget the regular education of the medical personnel and quality nursing care of patients with a urinary catheter.

\section{Conflict of interests}

The authors have no conflict of interests to declare.

\title{
Prevence močových infekcí souvisejících se zdravotní péčí z pohledu ošetřovatelské péče
}

\begin{abstract}
Souhrn
Cílem přehledové studie bylo shrnout závěry výzkumů o efektivitě opatření v oblasti prevence infekcí močových cest souvisejících se zdravotní péči (CAUTI) a zaměřit se na specifika ošetřovatelské péče $\mathrm{v}$ této oblasti. Zařazené studie a články byly vyhledány v elektronických databázích zaměřených na ošetřovatelství a další zdravotnické obory, a to jednak plnotextových (Cinahl, Ebsco, Nursing Ovid, ProQuest STM + Hospital Colection - Medline, Science Direct) a dále citačních (PubMed, Scopus), které byly využity k sekundárnímu dohledání relevantních zdrojů. Vybrané studie byly vyhledány pomocí klíčových slov: prevention, risk, infection, urinary tract, efficiency, nursing, dále dle dalších stanovených kritérií (plný text, recenzovaná periodika, anglický jazyk) a období publikace výsledků výzkumu posledních sedmi let, tedy 2011-2018. Do konečného přehledu bylo zařazeno 11 studií, které splnily požadovaná kritéria. Studie (kvalitativní studie, observační studie, kvaziexperimentální studie, popisná studie, studie) většinou specifikují rizikové oblasti pro vznik infekcí močových cest souvisejících se zdravotní péčí a věnují se efektivitě implementovaných preventivních opatření vycházejících z doporučených postupů prevence CAUTI. Jako přínosné intervence se jeví multifaktoriální opatření - vzdělávání zdravotníků v dané problematice, zavádění protokolů péče o pacienta $\mathrm{s}$ močovým katétrem, standardy péče a akceptace relevantních indikací katetrizace močového měchýře.
\end{abstract}

Klíčová slova: efektivita; infekce; močové ústrojí; ošetřovatelství; prevence; riziko 


\section{References}

1. AACN Practice Alert (2016). Prevention of catheer-associated urinary tract infections in adults. Crit Care Nurse 36(4): e9-e11. DOI: $10.4037 / \mathrm{ccn} 2016208$.

2. Alexaitis I, Broome B (2014). Implementation of a nursedriven protocol to prevent catheter-associated urinary tract infections. J Nurs Care Qual 29(3): 245-252. DOI: 10.1097/ NCQ.0000000000000041.

3. Andreessen L, Wilde P, Herendeen P (2012). Preventing catheter-associated urinary tract infections in acute care. J Nurs Care Qual 27(3): 209-217. DOI: 10.1097/ NCQ.0b013e318248b0b1.

4. Carter EJ, Pallin DJ, Mandel L, Sinnette C, Schuur JD (2016). A qualitative study of factors facilitating clinical nurse engagement in emergency department catheter-associated urinary tract infection prevention. J Nurs Adm 46(10): 495-500. DOI: 10.1097/NNA.0000000000000392.

5. Carter NM, Reitmeier L, Goodloe LR (2014). An evidence-based approach to the prevention of catheter-associated urinary tract infections. Urol Nurs 34(5): 238-245. DOI: 10.7257/1053816X.2014.34.5.238.

6. Conway LJ, Larson EL (2012). Guidelines to prevent catheterassociated urinary tract infection: 1980 to 2010. Heart Lung 41(3): 271-283. DOI: 10.1016/j.hrtlng.2011.08.001.

7. Fuchs MA, Sexton DJ, Thornlow DK, Champagne MT (2011). Evaluation of an evidence-based, nurse-driven checklist to prevent hospital-acquired catheter-associated urinary tract infections in intensive care units. J Nurs Care Qual 26(2): 101-109. DOI: 10.1097/NCQ.0b013e3181fb7847.

8. Gould CV, Umscheid CA, Agarwal RK, Kuntz G, Pegues DA, Healthcare Infection Control Practices Advisory Committee (HICPAC) (2009, update 2017). Guideline for prevention of catheter-associated urinary tract infections. [online] [cit. 201808-06]. Available from: https://www.cdc.gov/infectioncontrol/ pdf/guidelines/cauti-guidelines.pdf

9. Hedlová D (2010). Možnosti prevence infekcí močových cest spojených s katetrizací močového měchýře. Zdravotnictví a medicína. Sestra 20(10): 74-78.

10. Jain M, Dogra V, Mishra B, Thakur A, Loomba PS (2015). Knowledge and attitude of doctors and nurses regarding indication for catheterization and prevention of catheterassociated urinary tract infection in a tertiary care hospital. Indian J Crit Care Med 19(2): 76-81. DOI: 10.4103/09725229.151014.

11. Jindrák V, Hedlová D, Urbášková P (2014). Antibiotická politika a prevence infekcí v nemocnici. Praha: Mladá fronta.

12. Jirouš J (2012). Prevence infekce močových cest. Česká společnost nemocniční epidemiologie a hygieny. [online] [cit. 2018-08-06]. Available from: https://www.sneh.cz/_soubory/_ clanky/30.pdf

13. Kohoutová J (2014). Uroinfekce spojené se zdravotní péčí epidemiologie, prevence. Urol Praxi 11(1): 30-31.

14. Marečková J, Klugarová J, Klugar M, Jarošová D, Zeleníková R, Gurková E (2015). Evidence-Based HealthCare: Zdravotnictví založené na vědeckých důkazech. Olomouc: Univerzita Palackého v Olomouci.

15. McNeill L (2017). Back to basics: How evidence-based nursing practice can prevent catheter-associated urinary tract infections. Urol Nurs 37(4): 204-206.
16. Meddings J, Rogers MA, Krein SL, Fakih MG, Olmsted RN, Saint S (2014). Reducing unnecessary urinary catheter use and other strategies to prevent catheter-associated urinary tract infection: an integrative review. BMJ Qual Saf 23(4): 277-289. DOI: 10.1136/bmjqs-2012-001774.

17. Ministry of Health of the Czech Republic (2013). Metodický návod. Program prevence a kontroly infekcí v zdravotnických zařízeních poskytovatelů akutní lůžkové péče. [online] [cit. 2018-08-06]. Available from: http://www.mzcr.cz/Verejne/ obsah/program-prevence-a-kontroly-infekci-v-zdravotnickychzarizenich_2917_5.html

18. Oman KS, Makic MB, Fink R, Schraeder N, Hulett T, Keecht T, Wald H (2012). Nurse-directed interventions to reduce catheterassociated urinary tract infections. Ame J Infect Control 40(6): 548-553. DOI: 10.1016/j.ajic.2011.07.018.

19. Peter S, Devi ES, Nayak SG (2018). Effectiveness of clinical practice guidelines on prevention of catheter-associated urinary tract infections in selected hospitals. JKIMSU 7(1): 55-66.

20. Pintar PA (2013). An intrepreneurial innovative role: integration of the clinical nurse specialist and infection prevention professional. Clin Nurse Spec 27(3): 123-127. DOI: 10.1097/NUR.0b013e31828c8391.

21. Podrazilová P (2016). Minimalizace rizika vzniku infekcí spojených se zdravotní péčí u permanentního močového katétru pomocí rozhodovacího procesu. Urol praxi 17(1): 40-44.

22. Powers J (2016). Impact of an aseptic procedure for breaking the integrity of the urinary drainage system on the development of catheter-associated urinary tract infections in the intensive care unit. Intensive Crit Care Nurs 37: 82-85. DOI: 10.1016/j. iccn.2016.06.003.

23. Purvis S, Gion T, Kennedy G, Rees S, Safdar N, Van Den Bergh S, Weber J (2014). Catheter-associated urinary tract infection: a successful prevention effort employing a multipronged initiative at an academic medical center. J Nurs Care Qual 29(2): 141-148. DOI: 10.1097/NCQ.0000000000000037.

24. Sujijantararat R, Booth RZ, Davis LL (2005). Nosocomial urinary tract infection nursing-sensitive quality indicator in a Thai hospital. J Nurs Care Qual 20(2): 134-139.

25. Tenke P, Kovacs B, Bjerklund Johansen TE, Matsumoto T, Tambyah PA, Naber KG (2008). European and Asian guidelines on management and prevention of catheter-associated urinary tract infections. Int J Antimicrob Agents 31(Suppl. 1): 68-78. DOI: 10.1016/j.ijantimicag.2007.07.033.

26. Trautner BW (2010). Management of catheter-associated urinary tract infection. Curr Opin Infect Dis 23(1): 76-82. DOI: 10.1097/QCO.0b013e328334dda8.

27. Underwood L (2015). The effect of implementing a comprehensive unit-based safety program on urinary catheter use. Urol Nurs 35(6): 271-279.

28. Wilde MH, McMahon JM, McDonald MV, Wan T, Wenjuan W, Brasch (2015). Self-management intervention for longterm indwelling urinary catheter users: Randomized clinical trial. Nurs Res 64(1): 24-34. DOI: 10.1097/ NNR.0000000000000071.

29. Yatim J, Wong K-S, Ling M-L, Tan S-B, Tan K-Y, Hockenberry M (2016). A nurse-driven process for timely removal of urinary catheters. Int J Urol Nurs 10(3): 167-172. DOI: 10.1111/ ijun.12113. 